\section{Questión}

Periodismo / Comunicación ISSN 1669-6581
- Av. $44 \mathrm{~N}^{\circ} 676,1^{\circ}$ piso

CP 1900 - La Plata - Argentina

www.perio.unlp.edu.ar/question

Teatro: el virus de la creatividad. Entrevista sonora a la actriz Julieta Vallina por Carlos Milito

Carlos Milito

DOI: https://doi.org/10.24215/16696581e289

\title{
Teatro: el virus de la creatividad
}

Entrevista sonora a la actriz Julieta Vallina

\section{Theatre: The Virus of Creativity}

Sound interview with actress Julieta Vallina

Julieta Vallina es platense, actriz y docente, relata sus experiencias en el marco de la pandemia que obliga a repensar la profesión en tiempos de aislamiento, pero también en ese futuro donde se construya la "nueva normalidad".

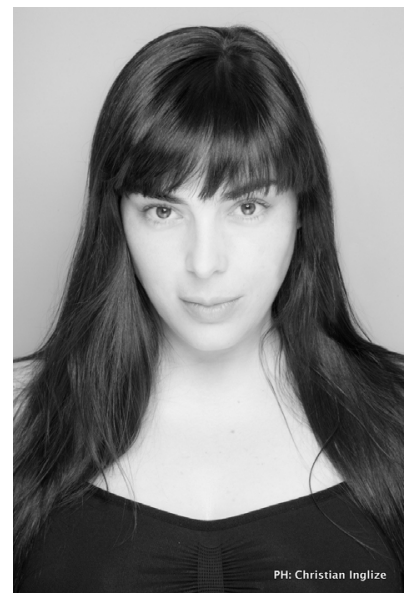


Entrevista completa:

https://ar.ivoox.com/es/51072960 